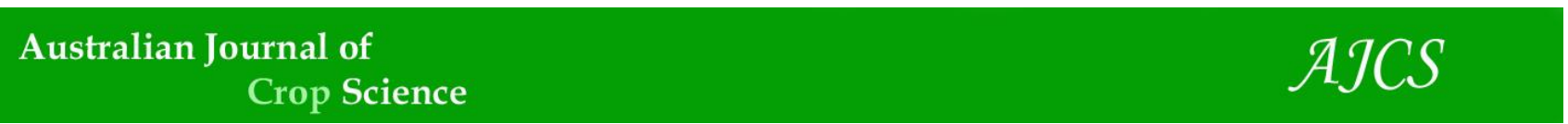

AJCS 14(08):1259-1263 (2020)

ISSN:1835-2707

doi: 10.21475/ajcs.20.14.08.p2377

\title{
Influence of bifurcation on thinning, productivity and harvester production costs
} of Pinus taeda L.

\author{
Carlos Cézar Cavassin Diniz ${ }^{1}$, Romano Timofeiczyk Junior ${ }^{1}$, Renato Gonçalves Robert ${ }^{1}$, Eduardo da Silva \\ Lopes $^{2}$, João Carlos Garzel Leodoro da Silva ${ }^{1}$, Felipe Martins de Oliveira ${ }^{3}$, Gustavo Silva Oliveira*1 \\ ${ }^{1}$ Department of Forestry Sciences, Federal University of Paraná - UFPR, Curitiba, Paraná, Brazil \\ ${ }^{2}$ Department of Forest Engineering, State University of the Center-West, Irati - Paraná, Brazil \\ ${ }^{3}$ Latin American Union of Technology (ULT-FAJAR), Faculdade Jaguariaíva, Jaguariaíva, Paraná, Brazil
}

*Corresponding author: gustavo_ccp@hotmail.com

\begin{abstract}
In this work, we present that how bifurcation in Pinus trees can influence productivity and harvester production costs. Our example draws from one harvesting machine that works in thinning operations in forest plantations of Pinus taeda L. in a small Brazilian forestry company. To get daily productivity, we use the machine's system, which provides such daily information as total production. We also used a time and motion study to obtain the meantime to cut, delimb, and process the tree stem into logs. In this way, we separated the normal trees from the forked trees to get the operating cycle time of the machine and get the productivity to the two types of trees. The continuous timing method was used for this purpose. The results show an increase of up to $22.9 \%$ in the operational cycle time for cutting forked trees, resulting in reduction of productivity of $5.58 \mathrm{~m}^{3}$ for each hour worked. The production cost increased by $23.3 \%$ on operation of forked trees, as the machine took more time to perform the partial activities of the operational cycle. This study can help many companies and contractors to calculate the appropriate productivity and production harvest cost according to the type of tree stems from the plantation forest.
\end{abstract}

Keywords: Forest operations; forked trees; cut-to-length.

Abbreviations: MIV_Mean individual volume, DBH_Diameter at breast height, DMA_Degree of mechanical availability, OE_Operational efficiency, UR_Utilization rate, PR_Productivity, EMT_Effective mean time.

\section{Introduction}

Mechanized logging activity has significantly contributed to maximize the return on investments made by companies and investors in planted forest businesses (Leite et al., 2014). The use of large machines to perform such activity reduces the contingent of labor, proposes improvements in safety conditions and ergonomics at work, and provides greater assurance of supplying industries with a regular and standardized wood supply (Bramucci and Seixas, 2002; Spinelli et al. 2009).

The productivity of a certain operation is influenced by external variables and the machines and implements themselves. In addition to these, Lopes and Pagnussat (2017) complement this by citing the level of technology, operator training, plantation conditions, mechanical availability and operational efficiency.

Knowledge of the different operating conditions and the equipment itself is of great importance, since they have a direct influence on the productivity of the equipment (Malinovski et al. 2006). The operational efficiency of the harvester is related to the tree's volume. Therefore, decreasing of the volume also decreases the operating income (Akay et al., 2004).

Thus, it is essential to carry out studies on the variables, which influence the productivity of wood harvesting equipment, as this will provide information, leading to minimizing costs and optimizing operations. Identification of these variables can be accomplished by time and movement studies, which enable gauging the productivity of the operations.

For evaluation of technical and economical operation of the harvester, Martins et al. (2009) concluded that the mean volume per tree was the variable that best explained the effective operational capacity of the equipment. Bramucci and Seixas (2002) stated that the increase in forest density results in a reduction of individual tree volume, leading to a fall in harvester productivity. A fact confirmed by the study conducted by Eliasson (1999), in which average individual volume was one of the main factors influencing the productivity of the machines used in forest cutting operations. 
It is clear that one of the factors affecting the productivity of harvester cutting operations is the average individual volume (Jiroušek et al., 2007; Leite et al., 2013), which is also affected by variables of the plantation, terrain and planning. Forked trees and trunks are presented by Malinovski et al. (2006) as influential variables on the productivity of wood harvesting machines. However, the values of this influence on productivity are not presented by these authors, nor even in other studies, which cite bifurcation as an influencing factor Simões et al. (2014) and Fernandes et al. (2009).

Bifurcation influences the productivity of forest machines and has been more approached in other countries than Brazil. Thus, Acuna et al. (2017) verified an increase in harvester productivity with a volume increase per tree, but this increase was observed at lower rates in forked trees. According to Labelle et al. (2016), the presence of thick branches and bifurcations can negatively influence harvester productivity by up to $20 \%$.

Thus, it is important to know the factors which affect the productivity of harvested forestry. The aim of this work was to show how much fork trees can influence productivity and harvester production costs in thinning operations in forest plantations of Pinus taeda L.

\section{Results and Discussion}

A total of 2,647 harvester cycles were collected in cutting trees with no bifurcations and 1,923 cycles for forked trees. The minimum required calculated amount was 1,562 operating cycles for each one. The partial times of the harvester operating cycle for forked and non-forked trees is shown in Fig 1. It was verified that processing one forked tree requires more time than another without bifurcation, and a significant difference was detected by the Tukey test (p-value $<0.05$ ).

The increased need for head movements to finish tree processing is one of the main reasons for the longer time spent, since more cuts are required during processing, so the bifurcation connection is removed and the wood is harvested. This was confirmed by the "processing" activity, which represented $74.8 \%$ and $61.1 \%$ of the total operational cycle time on average for forked and non-forked trees, respectively. A similar result was obtained by Lopes et al. (2007) and Simões et al. (2010) in a technical and economical study of timber harvesting operation with a harvester, in which they verified $59.7 \%$ and $62.6 \%$ of the operational cycle time demanded in the partial processing activity. In addition, an increase of up to $22.9 \%$ in the operational cycle time for forked trees resulted in reducing productivity by $5.58 \mathrm{~m}^{3}$ for each hour worked.

This result seems to be obvious; however, what is implied in important information is how much this value differs from trees with straight trunks. Forked trees take an average of 12 more seconds to process than those with straight trunks. The applicability of this information is based on data from the forest inventory, when it becomes possible to obtain a prognosis of the cutting productivity with the harvester, when including the percentage of selected forked trees in the thinning, thus guaranteeing greater accuracy in the production of an area to be thinned.

The elements which completed the operational cycle were "search and clearing" with $24.4 \%$ and $28.4 \%$, followed by "displacement" with $19.6 \%$ and $28 \%$ of the total operational cycle time for trees with and without bifurcation, respectively. There was no significant difference for the Tukey test ( $p$-value $<0.05$ ) for these elements, showing that the trunk shape has no influence during displacement of the machine and at the moment when it is moving the head to perform the search and the felling of the tree. The time to perform the operational cycle was 43 seconds for a forked tree and 33 seconds for a straight tree, and these results were different by the Tukey test ( $p$-value $<0.05$ ).

The productivity and production cost of the harvester operating with different types of trunks are shown in Fig 2. A reduction in production costs with increased productivity was observed, which can be explained by the increase in time for processing a forked tree, corroborating that trees with forked trunks directly influence the productivity and production costs of forest cutting operations with a harvester.

Production costs were $\$ 3.88 / \mathrm{m}^{3}$ and $\$ 2.99 . \mathrm{m}^{-3}$ for forked and straight trees, respectively. Given the MIV of the trees in this study, this difference results in an increase of US\$0.158 per forked tree to be thinned, representing an increase of US\$0.89/ $\mathrm{m}^{3}$ in harvester production cost. In this study, the wood quality and its market price were not considered.

The average productivity of the harvester was 18.57 for forked trees and $24.08 \mathrm{~m}^{3} / \mathrm{h}$ for straight trees. Thus, there is a reduction of $22.9 \%$ in machine productivity. In addition, these values were close to those found by Labelle et al. (2016) with a $20 \%$ reduction for forked trees with thick branches. A mean individual volume (MIV) of $0.22 \mathrm{~m}^{3}$ was considered for the present work, in which it was clear that the forked trees demanded more time for processing, thereby directly affecting the machine productivity.

Harvester studies have demonstrated that there is a productivity variation as a function of diameter at breast height (DBH). In this sense, studies such as those by Gingras (1988), Holtzscher and Lanford (1997) and Elliasson (1999) have shown the effect of this variable on productivity in mechanized forest harvesting, which confirmed a correlation between these factors. As the plantations go to the second or other thinnings and consequent final cutting, one must take into account the marking of the remaining trees so that they are not forked, since Acuna et al. (2017) report that the impact on harvester productivity becomes more prominent as the volume of trees increased.

The graph in Fig 3 is presented in percentages of the obtained operational costs. Fixed costs (depreciation, interest, storage, taxes and insurance) accounted for $41.77 \%$, and variable costs (fuel, repairs and maintenance, lubrication and labor) accounted for $58.23 \%$.

Because it is a relatively new machine ( 510.4 hours), it is possible to improve the DMA, OE and UR indicators starting with micro-planning of the operation, avoiding unnecessary displacements and keeping a stock of spare hoses in the field. The low operational efficiency values are due to the operator adapting to the new machine and eventual operational stops.

Finally, a mean mechanical availability of $92.8 \%$ was observed, similar to that obtained by Simões et al. (2010) and Silva et al. (2010). The main problems involved are connected to the hydraulic part of the machine, especially the hoses located near the processor head which present premature wear when entering and contact with each other and with part of the machine or even with trees and end up 


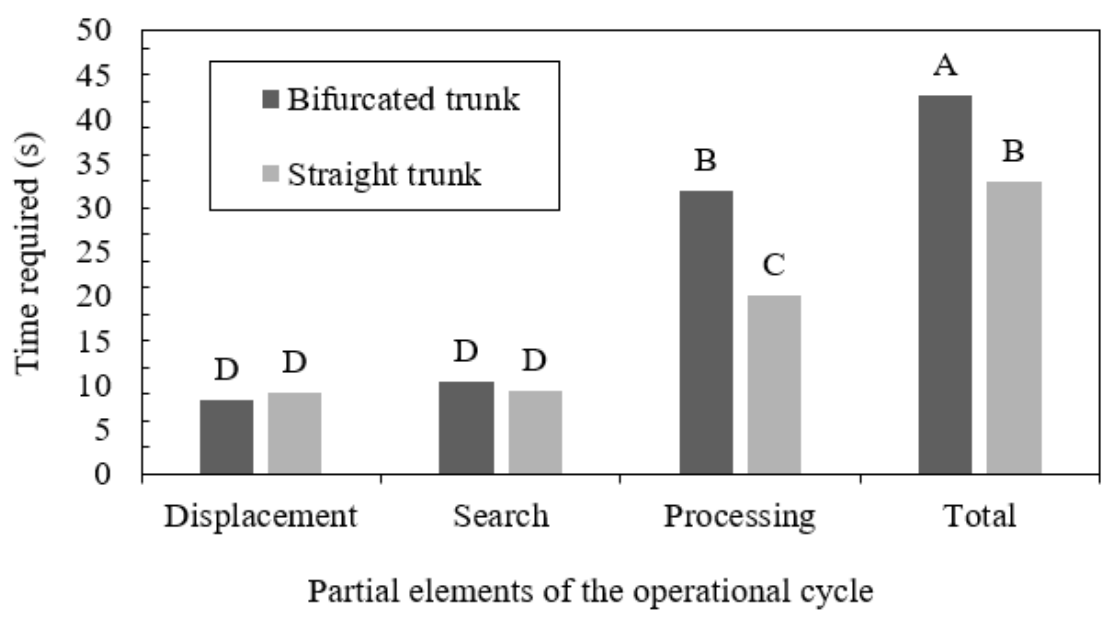

Fig 1. Partial times of the harvester operating cycle for forked and non- -forked trees. Means followed by the same letters do not differ statistically by the Tukey test at the $5 \%$ level of significance.

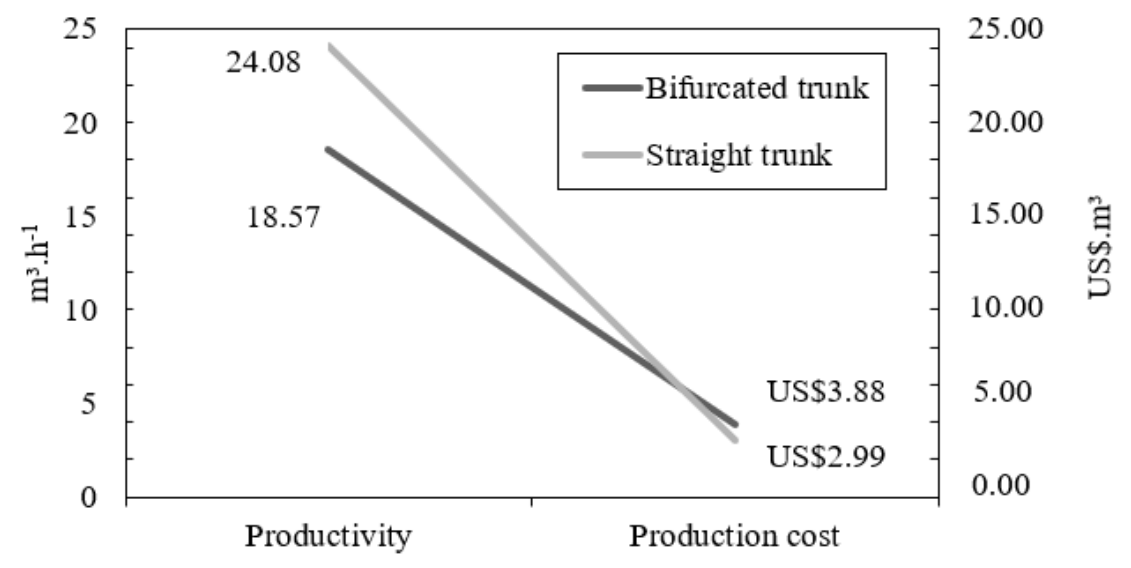

Fig 2. Productivity and production cost of the harvester operating with different trunk types.

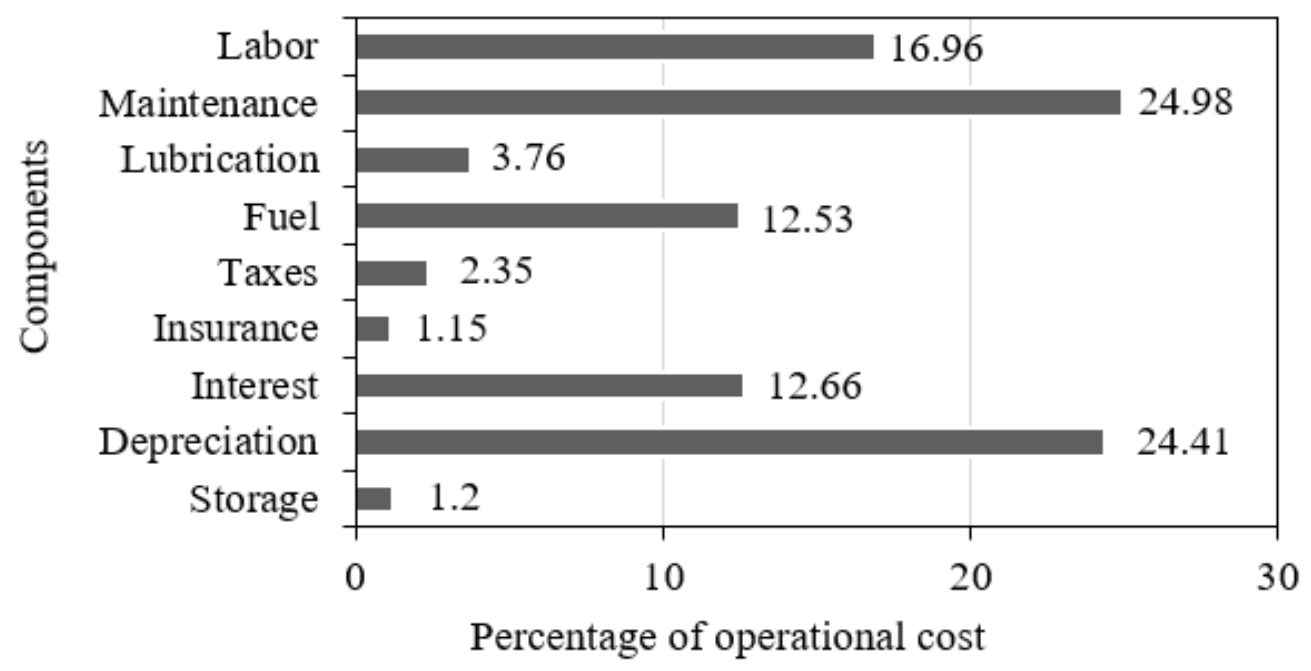

Fig 3. Harvester's Operational Cost Composition. 

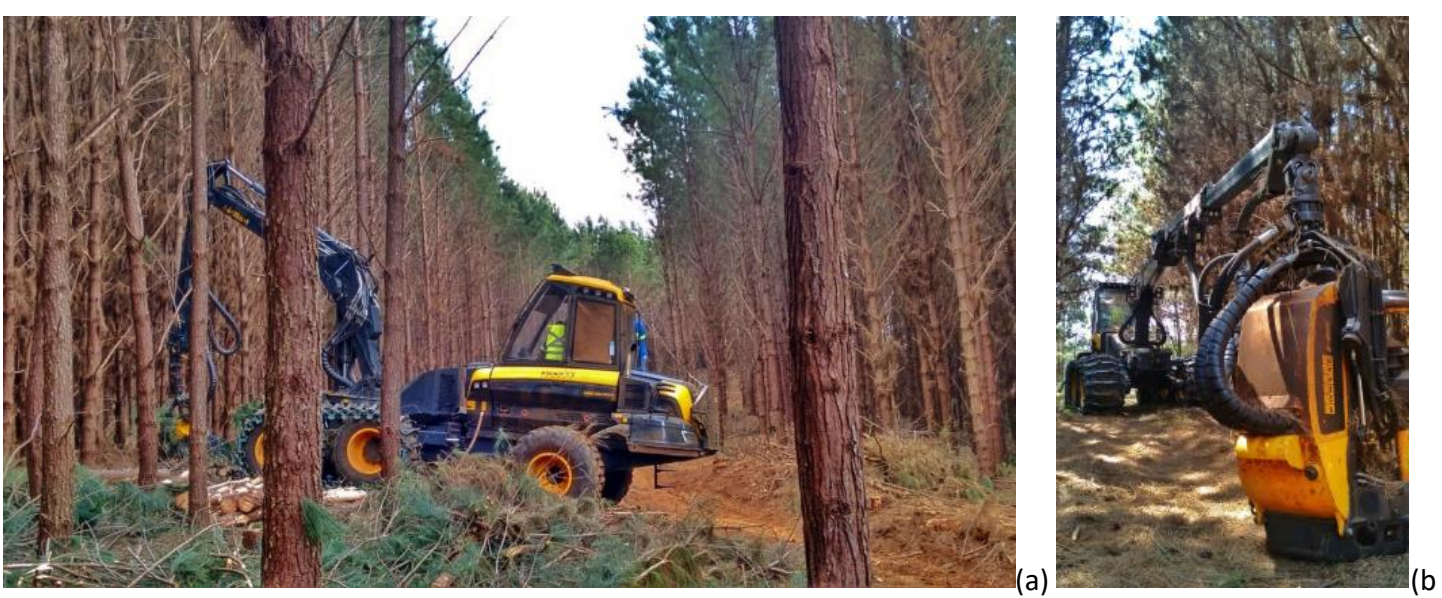

Fig 4. Ponsse beaver harvester at work (a). Processor head (b).

failing. The average operating efficiency was $77.5 \%$, and the average utilization rate was $71.9 \%$.

\section{Materials and Methods}

\section{Study characterization}

The study was carried out in an 11-year-old Pinus taeda L. forest plantation with a mean individual volume (MIV) of $0.22 \mathrm{~m}^{3}$ in the first thinning regime at a forest-based company located in the municipality of Inácio Martins, Paraná State, Brazil. The climate of the region is classified as $\mathrm{Cfb}$, with an average temperature of $17^{\circ} \mathrm{C}$ and average annual rainfall of $1,460 \mathrm{~mm}$. The shape of the trunk was considered as the main variable for this study, specifically the presence or absence of bifurcations, maintaining the other influencing factors as constant.

The wood harvesting system was cut-to-length, with the cutting and extraction operation implementing the mechanized method with the use of harvester and forwarder. The forest cutting was carried out by a Ponsse beaver harvester with a Mercedes-Benz/MTU OM 924 LA EU Stage IIIA engine, rated power of $145 \mathrm{~kW}$, an operational weight of $17,500 \mathrm{~kg}$, tires with $6 \times 6$ traction and a useful life of 510.4 hours (Fig 4).

\section{Problem description and general formulation}

A time and motion study was performed to obtain productivity information and the actual average operating cycle time of the machine. The continuous timing method was used for this purpose. The operational cycle was subdivided into the partial displacement activities (DI), characterized by the displacement of the machine between the trees; search and overturn (SO), including the movement of the boom and the head to the tree to be felled; processing (PR), being the overturning movement followed by the drive of the feed rollers and the cutting set for making the logs; and interruptions (INT), which are the unproductive operational and non-operational times. The production information $\left(\mathrm{m}^{3}\right)$, number of trees processed and MIV $\left(\mathrm{m}^{3}\right)$ were collected through the machine's operating systems using Timber Fleet software.
A pilot study was initially conducted to define the minimum number of observations, providing a maximum sampling error of $5 \%$, according to the formula proposed by Conaw (1977), and Simões et al. (2014):

$$
\mathrm{N} \geq \frac{\mathrm{t}^{2} \times C V^{2}}{\mathrm{E}^{2}}
$$

In which: $\mathrm{N}=$ minimum number of operating cycles; $\mathrm{t}=\mathrm{t}$ value for the $95 \%$ probability level; $\mathrm{CV}=$ coefficient of variation (\%); and $\mathrm{E}=$ permissible error (\%).

The mechanical availability represents the percentage of time the equipment is fit to work, discounting maintenance times (Silva et al., 2010) and was calculated by the formula:

$$
\mathrm{DMA}=\frac{\mathrm{TT}-\mathrm{MT}}{\mathrm{TT}} \times 10
$$

In which: DMA = degree of mechanical availability (\%); TT = total working time programmed (hours); MT = maintenance time (hours).

The operational efficiency was calculated from the available time that the equipment had to operate already discounting the mechanical pauses and subtracting the technical pauses on the time available, as calculated by the formula:

$$
\mathrm{OE}=\frac{\mathrm{TP}-\mathrm{TB}}{\mathrm{TP}} \times 100
$$

In which: OE = operational efficiency (\%); TP = total working time programmed, already discounting the mechanical pauses (hours); TB = time of technical breaks (hours).

The utilization rate represents the percentage of time the equipment actually operated, given by the formula:

$$
\mathrm{UR}=\mathrm{MA} \times \mathrm{OE}
$$

In which: $U R=$ utilization rate (\%); $M A=$ mechanical availability (\%); OE = operational efficiency (\%).

The productivity of the machine was calculated from the equation adapted from Fernandes et al. (2013), given in cubic meters of processed wood per hour of actual work:

$$
\mathrm{PR}=\frac{\mathrm{N} \times \mathrm{MIV}}{\mathrm{HE}}
$$

In which: $\mathrm{PR}=$ produtivity $\left(\mathrm{m}^{3} \cdot \mathrm{he}^{-1}\right) ; \mathrm{N}=$ number of trees; MIV = mean individual volume $\left(\mathrm{m}^{3}\right)$; and $\mathrm{HE}=$ effective working time (hours).

The equation proposed by Miyajima et al. (2016) was used to obtain the values of the effective mean operational cycle time, obtained through the ratio between the sum of the 
effective times of the operational cycles and number of cycles for each type of tree studied, being those with presence and absence of bifurcation:

$$
\mathrm{EMT}=\frac{\sum \mathrm{EMT}}{\mathrm{n}}
$$

In which: $E M T=$ effective mean time (minutes); $\sum E M T=$ sum of the effective working time (minutes); $n=$ number of operating cycles.

Production costs were estimated according to the methodology proposed by the American Society of Agricultural Engineers (Asae, 2001) and were expressed in US dollars.

In order to estimate production costs, fixed costs (depreciation, interest on invested capital, taxes and insurance) and variables (fuels, repairs and maintenance, lubricants and labor) were considered. Operating cost (US\$/he) was obtained by summing fixed and variable costs,

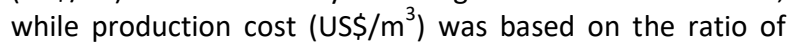
operating cost to productivity. An interest rate of $10 \%$ per annum and a 4-year useful life was considered, with a residual value of $48 \%$.

The obtained results were submitted to analysis of variance for completely randomized experiments, using $\mathrm{R}$ statistical software (R-Statistics). The Tukey test was performed at 5\% probability in the cases where there was a statistically significant difference.

\section{Conclusions}

Forked trees influence the increase in the time demanded by the harvester's operational cycle, a reduction in its productivity and an increase in its production cost of around $23 \%$, not only causing greater losses in wood quality, but also in the profit to be obtained by cubic meter of forked trees in the first thinning when the influencing factors are not taken into account.

The influence on the operational cycle time, productivity and production costs basically occurs due to the longer time required in the tree processing, with the displacement and the search and felling not influencing the composition of these values.

\section{Acknowledgements}

The authors thank the Lombão Florestal company for the support and their concession of any structure to carry out the study. This work was developed with financial support from the Coordination of Improvement of Higher Education Personnel (CAPES) - Financing Code 001.

\section{References}

Acuna M, Strandgard M, Wiedemann J, Mitchell R (2017) Impacts of an early thinning of a Eucalyptus globulus Labill. Pulp log plantation in Western Australia on economic profitability and harvester productivity. Forests - Forest Operations. Engineering and Management. 142-155.

Akay $A E$, Erda O, Sessions J (2004) Determining productivity of mechanized harvesting machines. J Applied Sci. 4: 100-105.
American society of agricultural engineers (2001) Asae standards: machinery, equipment, and buildings: operating costs. Ames. 566. Bramucci M, Seixas F (2002) Determinação e quantificação de fatores de influência sobre a produtividade de Harvesters na colheita florestal. Scientia Florestais. 62: 62-74.

Conaw PL (1977) Estatística. São Paulo: Edgard Blucher. 264p.

Eliasson $L$ (1999) Simulation of thinning with a single-grip harvester. Forest Science. 45: 26-34.

Fernandes HC, Burla ER, Leite ES, Minette L (2013) Avaliação técnica e econômica de um "Harvester" em diferentes condições de terreno e produtividade da Floresta. Scientia Forestalis. 41:141-151.

Fernandes HC, Lopes SE, Teixeira MM, Minette $L$, Rinaldi PCN, Bernardes AM (2009) Avaliação das características técnica e econômica de um sistema de colheita florestal de árvores inteiras. Scientia Forestalis. 37(83): 225-232.

Gingras JF (1988) The effects of site and stand factors on fellerbuncher performance. FERIC Technical Report. 84:1-18.

Holtzscher MA, Lanford BL (1997) Tree diameter effects on cost and productivity of cut-to-lenght systems. Forest Products Journal. 47(3):25-30.

Jiroušek R, Klvač R, Skoupý A (2007) Productivity and costs of the mechanized cut-to-length wood harvesting system in clear-felling operations. Journal of Forest Science. 53(10):476-482.

Leite ES, Fernandes HC, Minette LJ, Leite HG, Guedes IL (2013) Modelagem técnica e de custos do Harvester no corte de madeira de eucalipto no sistema de toras curtas. Scientia Forestalis. 41(98):205-215.

Leite ES, Minette LJ, Fernandes HC, Souza AP, Amaral EJ, Lacerda EG (2014) Desempenho do Harvester na colheita de eucalipto em diferentes espaçamentos e declividades. Revista Árvore. 38(1):000-000.

Lopes ES, Cruziniani E, Dias NA, Fiedler NC (2007) Avaliação técnica e econômica do corte de madeira de pinus com cabeçote Harvester em diferentes condições opercaionais. Floresta. 37(3):305-313.

Lopes ES, Pagnussat MB (2017) Effect of the behavioral profile on operator performance in timber harvesting. International Journal of Forest Engineering 0:1-6.

Malinovski RA, Malinovski RA, Malinovski JR, Vamaji FM (2006) Análise das variáveis de influência na produtividade das máquinas de colheita de madeira em função das características físicas do terreno, do povoamento e do planejamento operacional florestal. Revista Floresta. 36(2):169-182.

Martins RJ, Seixas F, Stape JL (2009) Avaliação técnica e econômica de um Harvester trabalhando em diferentes condições de espaçamento e arranjo de plantio em povoamento de eucalipto. Scientia Florestais. 37(83):253-263.

Miyajima RH, Tonin RP, Passos JRS, Fenner PTA (2016) Influência da declividade do terreno e do tempo de experiência dos operadores no rendimento do Feller buncher. Scientia Forestalis. 44(10):443 451.

Silva EM, Machado CC, Minette $L$, Souza AP, Fernandes HC, Silva ML, Jacovine LA (2010) Avaliação técnica e econômica do corte mecanizado de Pinus sp. com Harvester. Revista Árvore. 34(4):745-753.

Simões D, Fenner PT, Esperancini MST (2010) Avaliação técnica e econômica da colheita de florestas de eucalipto com Harvester. Scientia Forestalis. 38(88):611-618.

Simões DF, Fenner PT, Esperancini MST (2014) Produtividade e custos do Feller buncher e processador florestal em povoamento de eucalipto de primeiro corte. Ciência Florestal. 24(3):621-630.

Spinelli R, Wardb SM, Owendec PM (2009) A Harvest and transport cost model for Eucalyptus spp. fast-growing short rotation plantations. Biomass and Bioenergy. 33(9): 1265-1270. 